\title{
Tratamento dos Mortos entre os Sambaquieiros, Tupinambá e Goitacá que ocuparam a Região dos Lagos, Estado do Rio de Janeiro
}

\author{
Maria Dulce Gaspar* \\ Angela Buarque** \\ Jeanne Cordeiro** \\ Eliana Escórcio ***
}

\begin{abstract}
GASPAR, M.D.; BUARQUE, A.; CORDEIRO, J.; ESCÓRCIO, E. Tratamento dos Mortos entre os Sambaquieiros, Tupinambá e Goitacá que ocuparam a Região dos Lagos, Estado do Rio de Janeiro. Revista do Museu de Arqueologia e Etnologia, São Paulo, 17: 169-189, 2007.
\end{abstract}

Resumo: $\mathrm{O}$ artigo tem como objetivo estabelecer uma dimensão comparativa entre diferentes grupos culturais que ocuparam a Região dos Lagos, litoral sudeste do Brasil, focando o estudo do ritual funerário, aqui entendido como um aspecto central da vida social. Apresentamos o processo de colonização da região, considerando-a como uma área piloto que guarda importantes informações sobre a ocupação da porção leste da América do Sul. Dessa forma, o estudo aborda colonização, interação social e controle de território relacionado aos grupos Sambaquieiro, Tupi e Macro-Jê e procura correlacionar informações provenientes da arqueologia, antropologia, história, bem como relatos dos cronistas.

Palavras-chave: Ritual funerário - Sambaquieiros - Tupinambá e Goitacá.

\section{Introdução}

O artigo tem como objetivo caracterizar o ritual funerário dos Sambaquieiros, Tupinambá e Goitacá que habitaram a Região

(*) Museu Nacional da Universidade Federal do Rio de Janeiro-UfRJ. Pesquisadora do CNPq. madugaspar@terra.com.br

$\left({ }^{* *}\right)$ Museu Nacional da Universidade Federal do Rio de Janeiro-UFRJ. Pesquisadora Associada. abuarqu@terra.com.br $\left.{ }^{* * *}\right)$ Departamento de Antropologia, Museu Nacional da Universidade Federal do Rio de Janeiro-UFRJ. jeanne.cordeiro@terra.com.br

$\left({ }^{* * *}\right)$ Museu Nacional da Universidade Federal do Rio de Janeiro-UFRJ. Mestranda em Arqueologia.

e.escorcio@terra.com.br dos Lagos, no litoral do Rio de Janeiro. Parte do princípio de que a maneira de lidar com a morte está relacionada com a organização cognitiva do universo de cada cultura e é um traço diacrítico que permite estabelecer limites e fronteiras entre diferentes grupos sociais. É um desdobramento das reflexões de Gaspar $(1991,1993)$ que estabeleceu critérios para delimitar a "individualidade coletiva" relativa aos sambaquis, inspirada no trabalho de Marcel Mauss (1974). A autora discute a noção de etnia, desenhada a partir do registro arqueológico, que considera como construída pelo pesquisador e que ganha consistência a partir do contraste com outros conjuntos de vestígios que lhes são contemporâneos. No que se refere à sociedade sambaquieira, 
o estudo de outros conjuntos delineados para a pré-história brasileira indicou que os aspectos ressaltados - construção de mound através do acúmulo de corpos e/ou parte de animais marinhos e o sepultamento dos mortos - são traços diacríticos desta sociedade. Essa reflexão parte do princípio de que o espaço é um aspecto estruturador da vida em sociedade, de que existe uma estreita relação entre o que uma coisa é e o lugar no qual ela está situada.

Os rituais funerários são episódios, ritos de passagem, como quer van Gennep (1978), que mobilizam, envolvem e reordenam todos os membros das sociedades ditas "simples" e que são característicos e exclusivos a cada sistema sociocultural. Consideramos que o ritual funerário é um domínio da vida social associado à cosmogonia de cada grupo cultural e, por isso mesmo, apropriado para estabelecer comparações entre sociedades. Partindo desse princípio, a equipe do Museu Nacional decidiu estudar programas funerários de grupos culturais distintos em uma mesma região. Dedicamo-nos à pesquisa do processo de colonização da Região dos Lagos, considerada uma área piloto, que está relacionado com a ocupação da porção leste da América do Sul. Nosso estudo aborda colonização, interação social e controle de território relacionado aos grupos Sambaquieiros, Tupi, particularmente os Tupinambá, e Macro-Jê, especialmente os Goitacá.

Buarque, desde 1993, estuda os Tupinambá, que ocuparam a região dos Lagos, e já produziu reflexões sobre o tratamento dos mortos entre esses nativos (Buarque et al. 2003; Gaspar et al. 2004; Buarque 2004 mimeo). Cordeiro, desde 2000, estuda os Goitacá, e, também, se dedica ao estudo dos Tupinambá (2004 , 2005). Mais recentemente, Escórcio \& Gaspar (2005) iniciaram reflexões sobre construção de gênero entre os sambaquieiros.

\section{Sambaquieiros, Tupi e Macro-Jê - suas princi- pais características}

Embora nos estados vizinhos, como Minas Gerais e São Paulo, sejam abundantes os testemunhos arqueológicos dos caçadores que ocuparam o que veio a ser o Brasil, e apesar da existência de pesquisa sistemática, não há sítios indubitavelmente relacionados com este grupo no interior do estado do Rio de Janeiro. O rio Paraíba do Sul, uma das rotas de acesso privilegiadas posteriormente pelos ceramistas para sua dispersão pelo território fluminense, parece ter funcionado como uma barreira natural para os caçadores que iniciaram a colonização do Brasil, embora haja cadastro de alguns poucos sítios líticos que ainda não foram objeto de escavação e que podem estar associados aos caçadores ou aos grupos ceramistas.

Os sambaquis têm em média $2 \mathrm{~m}$ de altura por $30 \mathrm{~m}$ de largura e $50 \mathrm{~m}$ de comprimento. Não se sabe ao certo quando seus primeiros construtores chegaram à costa, já que, em decorrência da variação do nível do mar, os registros mais antigos dos sambaquieiros teriam sido inundados. Para o litoral brasileiro, há datações isoladas de 9 mil e 10 mil anos que precisam ser confirmadas (De Blasis 2002), mas é certo que, por volta de $7 \mathrm{mil}$ anos, o litoral começava a ser intensamente ocupado. Porém, para a área em estudo a data mais antiga é proveniente do sambaqui do Forte que informa que por volta de 5.500 anos o modo de vida dos sambaquieiros estava em pleno funcionamento (Kneip 2001). Como se pode depreender da análise do quadro 1, entre 4 e 3 mil anos são inúmeras as referências cronológicas para este tipo de sítio, o que sugere que este período referese ao momento de expansão da sociedade sambaquieira na Região dos Lagos. Por outro lado, a desestruturação desta sociedade parece ter começado a ocorrer em torno do início da era Cristã (Quadro 1) .

A principal atividade de subsistência dos sambaquieiros era a pesca, complementada pela coleta de vegetais e moluscos, sendo o cuidado com os mortos um aspecto da vida social de suma importância. Corpos de homens, mulheres e crianças eram depositados em locais especialmente construídos para recebê-los. O sambaqui caracteriza-se por ser, em especial, o local dos mortos e é um espaço diferenciado que, pelo seu volume e concentração de material orgânico, destaca-se na paisagem. Outros materiais poderiam ter sido usados, mas a escolha recaiu sobre aqueles intrinsecamente relacionados ao 
domínio alimentar. O espaço em questão é um lugar bastante particular apresentando condições especiais no que se refere à textura, relevo, odores e acidez do solo.

Os Tupinambá eram populações agricultoras e ceramistas relacionadas ao tronco lingüístico Tupi. No estado do Rio de Janeiro, a vasta faixa litorânea, em particular o entorno da Baía de Guanabara, Guaratiba e a Região dos Lagos foram os espaços em que a ocupação foi mais intensa. Existem dezenas de hipóteses que procuram explicar o seu processo de origem e dispersão, sendo a Amazônia aceita pela quase totalidade dos pesquisadores (Lathrap 1970; Brochado 1984; Scatamacchia 1990; Dias Jr.1994/1995; Noelli 1996; Dias Jr.1998; Heckenberger et al. 1998), o dissenso refere-se à localização geográfica e às direções das rotas de expansão (Noelli 1996).

Os Goitacá, por sua vez, são falantes de uma das línguas Macro-Jê e originários do Centro Oeste do Brasil (Maybury-Lewis 1979; Urban 1992). O estudo das cerâmicas agrupadas sob a denominação de tradição Una aponta, também, o Centro Oeste brasileiro como a região de origem, e o sítio mais antigo está datado de 410 anos a. C. (RobrahnGonzález 1996). Na região Sudeste, os materiais arqueológicos estão datados de $920 \pm 60$ anos AP, o que indica a instalação dos Goitacá em pleno território sambaquieiro (Cordeiro 2004) (Quadro 1).

Os Macro-Jê, também, estavam na costa no período da invasão européia e entraram em contato com portugueses e franceses, havendo referências a sua presença até o século XIX. Mas se, por um lado, são inúmeros os relatos sobre os Tupi, pouco se escreveu sobre os Goitacá / Coroado, Puri, Macunim, Koropó, tendo havido o que se convencionou denominar de "tupinização" de todas as outras tribos e aos Goitacá restou o lugar do mais alto grau de barbárie (Cordeiro 2004). Segundo Jean de Léry, estudioso de teologia que veio para o Brasil em 1557, durante o período de instalação da França Antártica:

[...] Uetacá, indios tão ferozes que não podem viver em paz com os outros e se acham sempre em guerra aberta não só contra vizinhos mas, ainda contra todo os estrangeiros (...) Em suma esses diabólicos Uetacá, invenciveis nessa região, comedores de carne humana, como cães e lobos, e donos de uma linguagem que seus vizinhos não entendem, devem ser tidos entre os mais cruéis e terriveis que se encontram em toda a India ocidental." (Léry 1980:80).

Em síntese, por volta do início da era Cristã, o território dos sambaquieiros foi invadido por grupos ceramistas provenientes da Amazônia e Brasil Central. Esta ocupação parece ter sido o principal vetor de transformação do modo de vida dos pescadores e coletores.

\section{Interação entre os vários grupos tribais}

As referências cronológicas para a mudança no hábito de construir os sambaquis remetem a um período em torno do início da era Cristã. As mudanças observadas coincidem, em termos cronológicos, com uma reordenação espacial dos grupos sociais que ocupavam o leste da América do Sul. Em um momento inicial da colonização, por volta de 7.000 anos atrás, caçadores e sambaquieiros tinham territórios bem distintos, os primeiros espalharam-se pelo interior e os segundos exploraram intensivamente a faixa litorânea. Não há indícios de estreita interação social e competição por territórios nesse período. Há 5 mil anos atrás, mudanças sociais começaram a ser gestadas na região Amazônica e, nos últimos 2.000 anos, uma ebulição cultural ocorreu na região, envolvendo crescimento demográfico, mudanças profundas na economia e na organização social das populações. Dentre esses eventos, há o surgimento de grandes aldeias na Amazônia, Brasil Central e Pantanal que indica crescimento populacional e adoção de um estilo de vida mais sedentário e mais dependente da agricultura do milho e da mandioca. Inaugura-se, assim, uma nova maneira de manejar o ambiente e transformar a paisagem (Silva et al. 2004). 
Quadro 1

\begin{tabular}{|c|c|c|c|c|}
\hline $\begin{array}{l}\text { Filiação } \\
\text { Cultura }\end{array}$ & Sítios & $\begin{array}{c}\text { Idade } \\
\text { Convencional }\end{array}$ & $\begin{array}{c}\text { Resultados } \\
\text { Calibrados } 2 \\
\text { Sigma }\end{array}$ & $\begin{array}{l}\text { Referência } \\
\text { Bibliográfica }\end{array}$ \\
\hline \multirow[t]{44}{*}{ Sambaquieiro } & Madressilva & $3640 \pm 50$ & $2150-1880$ & Kneip 2001 \\
\hline & \multirow{7}{*}{ Manitiba I } & $3810 \pm 70$ & $2480-2110$ & \multirow[t]{7}{*}{ Kneip 2001} \\
\hline & & $3900 \pm 70$ & $2500-2190$ & \\
\hline & & $3940 \pm 50$ & $2580-2280$ & \\
\hline & & $3970 \pm 70$ & $2700-2200$ & \\
\hline & & $4030 \pm 70$ & $2900-2300$ & \\
\hline & & $4130 \pm 70$ & $2890-2550$ & \\
\hline & & $4270 \pm 70$ & $3040-2620$ & \\
\hline & Saco & $3540 \pm 50$ & $1980-1730$ & Kneip 2001 \\
\hline & \multirow[t]{2}{*}{ Jaconé } & $3350 \pm 80$ & $1780-1440$ & \multirow[t]{2}{*}{ Kneip 2001} \\
\hline & & $3760 \pm 70$ & $3760-2410$ & \\
\hline & \multirow[t]{2}{*}{ Saquarema } & $2550 \pm 60$ & $830-480$ & \multirow[t]{2}{*}{ Kneip 2001} \\
\hline & & $3280 \pm 60$ & $1690-1420$ & \\
\hline & \multirow[t]{2}{*}{ Moa } & $3610 \pm 190$ & $2600-1500$ & \multirow[t]{2}{*}{ Kneip 2001} \\
\hline & & $3960 \pm 200$ & $3100-1800$ & \\
\hline & \multirow[t]{3}{*}{ Pontinha } & $1790 \pm 50$ & $120 \mathrm{AD}-35 \mathrm{AD}$ & \multirow[t]{3}{*}{ Kneip 2001} \\
\hline & & $1810 \pm 40$ & $80 \mathrm{AD}-350 \mathrm{AD}$ & \\
\hline & & $2270 \pm 170$ & 800BC-100AD & \\
\hline & \multirow[t]{4}{*}{ Beirada } & $3.800 \pm 190$ & $2900-1780$ & \multirow[t]{4}{*}{ Kneip 2001} \\
\hline & & $4160 \pm 180$ & $3400-2200$ & \\
\hline & & $4300 \pm 190$ & $3600-2300$ & \\
\hline & & $4520 \pm 190$ & $3700-2650$ & \\
\hline & \multirow[t]{4}{*}{ Forte } & $5520 \pm 120$ & $4700-4000$ & \multirow[t]{4}{*}{ Kneip 2001} \\
\hline & & $4330 \pm 140$ & $3400-2550$ & \\
\hline & & $3940 \pm 140$ & $2900-2000$ & \\
\hline & & $2240 \pm 70$ & $410-90$ & \\
\hline & Salinas Peroano & $4340 \pm 70$ & $3350-2700$ & Gaspar 1991 \\
\hline & Boca da Barra & $3760 \pm 180$ & $2700-1600$ & Gaspar 1991 \\
\hline & Ponta da Cabeça & $3270 \pm 70$ & $1690-1400$ & Gaspar 1991 \\
\hline & Geribá II & $5510 \pm 110$ & $4250-3700$ & Tenório 1992 \\
\hline & Geribá I & $1480 \pm 90$ & 380AD-720AD & Tenório 1992 \\
\hline & Condomínio do Atalaia & $4190 \pm 190$ & $3350-2350$ & Tenório 2003 \\
\hline & \multirow[t]{4}{*}{ IBV I } & $3480 \pm 100$ & $2050-1500$ & \multirow[t]{4}{*}{ Gaspar 1998} \\
\hline & & $3410 \pm 60$ & $1880-1520$ & \\
\hline & & $3210 \pm 50$ & $1610-1390$ & \\
\hline & & $3110 \pm 60$ & $1520-1250$ & \\
\hline & \multirow[t]{2}{*}{ IBV II } & $3670 \pm 80$ & $2300-1750$ & \multirow[t]{2}{*}{ Gaspar 1998} \\
\hline & & $2060 \pm 60$ & 210BC-80AD & \\
\hline & IBV III & $2820 \pm 200$ & $1500-400$ & Gaspar 1998 \\
\hline & \multirow[t]{5}{*}{ IBV IV } & $1620 \pm 80$ & $50 \mathrm{AD}-240 \mathrm{AD}$ & \multirow[t]{5}{*}{ Gaspar 1998} \\
\hline & & $1920 \pm 60$ & $320 \mathrm{AD}-600 \mathrm{AD}$ & \\
\hline & & $3650 \pm 40$ & $2150-1740$ & \\
\hline & & $3740 \pm 110$ & $2500-1800$ & \\
\hline & & $3850 \pm 140$ & $2700-1850$ & \\
\hline
\end{tabular}


Quadro 1 (cont.)

\begin{tabular}{|c|c|c|c|c|}
\hline $\begin{array}{l}\text { Filiação } \\
\text { Cultura }\end{array}$ & Sítios & $\begin{array}{c}\text { Idade } \\
\text { Convencional }\end{array}$ & $\begin{array}{c}\text { Resultados } \\
\text { Calibrados } 2 \\
\text { Sigma }\end{array}$ & $\begin{array}{l}\text { Referência } \\
\text { Bibliográfica }\end{array}$ \\
\hline & Tambor & $3200 \pm 190$ & $1900-1050$ & $\begin{array}{l}\text { Mendonça de } \\
\text { Souza } 1997\end{array}$ \\
\hline & & $3635 \pm 135$ & $2500-1600$ & \\
\hline & Corondó & $4260 \pm 75$ & $3040-2620$ & Carvalho 1987 \\
\hline & & $3720 \pm 95$ & $2500-1800$ & \\
\hline & & $3215 \pm 90$ & $1690-1290$ & \\
\hline & & $3010 \pm 80$ & $1430-1000$ & \\
\hline & Malhada & $4020 \pm 80$ & $2900-2300$ & $\begin{array}{l}\text { Mendonça de } \\
\text { Souza } 1997\end{array}$ \\
\hline & & $3725 \pm 75$ & $2400-1850$ & \\
\hline & & $3580 \pm 80$ & $2150-1730$ & \\
\hline & & $3050 \pm 80$ & $1460-1040$ & \\
\hline & & $710 \pm 60$ & 1210AD-1400AD & \\
\hline & Itaúnas & $5700 \pm 70 \mathrm{BP}$ & $5740 \pm 70 \mathrm{BP}$ & \\
\hline & Mombaça & $4250 \pm 50 \mathrm{BP}$ & $3900 \pm 50 \mathrm{BP}$ & \\
\hline \multirow[t]{12}{*}{ Tupinambá } & Morro Grande & $2.200 \pm 70$ & 400AD-90AD & Buarque 1995 \\
\hline & & $1740 \pm 90$ & 80AD-470AD & \\
\hline & & $2600 \pm 160$ & $1250-350$ & $\begin{array}{c}\text { Macario 2003; } \\
\text { Buarque et al. } 2003\end{array}$ \\
\hline & & $510 \pm 160$ & & $\begin{array}{c}\text { Macario 2003; } \\
\text { Buarque et al. } 2003\end{array}$ \\
\hline & & 311 & & Latini 1998; \\
\hline & & & & Buarque et al. 2003 \\
\hline & Condomínio & $500 \pm 160$ & $1150 \mathrm{AD}-1850 \mathrm{AD}$ & Vinagre et al. 2000; \\
\hline & Jardim Bela Vista & & & Buarque et al. 2003 \\
\hline & Bananeiras & $430 \pm 40$ & & Buarque et al. 2003 \\
\hline & São José & $282 \pm 60$ & & Latini 1998 \\
\hline & Três Vendas & $200 \pm 125$ & & Kneip 1980 \\
\hline & & $185 \pm 120$ & & Kneip 1980 \\
\hline \multirow[t]{4}{*}{ Goitacá } & Grande do Una & $1065 \pm 90$ & 770 AD-1190AD & Dias 1969 \\
\hline & & $920 \pm 60$ & & Cordeiro 2004 \\
\hline & Frexeiras & $640 \pm 50 \mathrm{BP}$ & $1280-1410$ AD & \\
\hline & Sapeatiba & $520 \pm 70 \mathrm{BP}$ & $1300-1480 \mathrm{AD}$ & \\
\hline
\end{tabular}

Com os deslocamentos populacionais que ocorreram na Amazônia e no Brasil Central se dá todo um rearranjo dos grupos sociais que habitavam o território que veio a ser o Brasil. Houve deslocamentos de populações e intensificação dos contatos entre diferentes grupos culturais, com significativa interação social que acabou por ter forte impacto na vida dos sambaquieiros.
Inicialmente, os contatos entre os sambaquieiros e ceramistas parecem ter se restringido a trocas eventuais, o que explica a presença de cerâmica nos últimos níveis de ocupação (Kneip \& Machado 1993; Kneip 1994; Crancio \& Kneip 1994). Posteriormente, observam-se mudanças na estratigrafia de alguns sambaquis, com a presença de uma matriz terrosa, de cor marrom escura, com 
poucas conchas de moluscos, que se sobrepõe a uma matriz conchífera. ${ }^{1}$

Vários pesquisadores notaram essas alterações no pacote arqueológico e ressaltaram o menor predomínio de conchas entre os materiais que compõem os últimos níveis de ocupação e/ou os sítios mais recentes. Alguns sugerem a influência de mudanças ambientais para explicar as alterações notadas nos sítios arqueológicos (Dias Jr. \& Carvalho 1984). Porém, estas transformações no ambiente não foram confirmadas para a área em questão, já que Scheel-Ybert $(1998,1999)$, a partir de estudos antracológicos, aponta para estabilidade ambiental. Esta alteração no registro arqueológico dos sambaquis foi tomada, também, como reflexo de mudança na dieta alimentar (Kneip et al. 1980; Lima1991; Dias Jr. 1980), interpretação que se coaduna com o ideário da época, que considerava os sambaquis como formados a partir do acúmulo de restos alimentares. As pesquisas de Gaspar (1991), na região em foco, Afonso \& De Blasis (1994), Fish et al. (2000) e Klökler (2001), no sul do país, questionam esta interpretação e ressaltam a importância do ritual funerário no processo incremental dos sambaquis. ${ }^{2}$

A distribuição espacial e temporal dos sítios, também, aponta para a ocupação do território sambaquieiro. As aldeias Goitacá, denominadas de Grande do Una, Sapeatiba e Frexeiras estão todas situadas na planície litorânea, território que até 2 mil atrás era domínio exclusivo dos sambaquieiros.

Não se pode pensar em convivência pacífica entre esses grupos, não só em decorrência da expansão dos ceramistas e da invasão do território sambaquieiro, mas, sobretudo, porque as sociedades Tupinambá e Goitacá estruturavam-se a partir da guerra e/ou disputa corporal, comportamento social que parece não ter integrado

(1) Cabe destacar que esta ordenação de camadas também está descrita para sítios da região sul (Fish e colaboradores, 2000).

(2) Luby \& Gruber (1999) é um bom exemplo da corrente de pensamento que aponta para novas interpretações sobre as atividades relacionadas com a construção de mounds. os hábitos e costumes dos sambaquieiros (Lessa \& Medeiros 2001). ${ }^{3}$

Os sambaquieiros inauguraram a colonização da costa e, desta maneira, não disputaram o seu território com outro grupo social. A manutenção dos espaços ocupados, a expansão territorial e o aumento do número de sambaquis ao longo do tempo indicam que a sociedade dos pescadorescoletores estava em processo de replicação. A expansão parece ter se dado de maneira pacífica sem que a guerra ou a disputa corporal fizessem parte da estrutura social, apoiando-se em relativa estabilidade ambiental, territorial e baixa interação com outros grupos (Scheel-Ybert 1998; De Blasis et al. 1998). Estruturou-se, sobretudo, no cuidado com os mortos, instituição norteadora da sua vida social. Trata-se de uma sociedade que parece ter se preocupado muito mais com a manutenção de costumes do que com a busca e/ou incorporação de novos hábitos. Dessa maneira, quando se intensificou o contato com os ceramistas, a sociedade sambaquieira não foi capaz ou não teve tempo para criar uma resposta social que garantisse a manutenção de seu território e de seus costumes e entrou em colapso. Tornou-se inviável a continuidade do projeto de construir sambaquis.

A noção de colapso é inspirada nas reflexões de Diamond (2005:17) que se refere a uma drástica redução da população e/ou complexidade política, econômica e social, numa área considerável, durante um longo tempo. É aqui entendida como a alteração da ordem vigente e adequação a um novo modo de vida, sendo que, no caso em análise, parece correto pensar tanto na impossibilidade de manutenção de hábitos e costumes como na eliminação de um razoável contingente populacional, em decorrência do comportamento guerreiro dos Tupinambá e Goitacá e da tomada do território dos sambaquieiros por estes agricultores e ceramistas.

Como os Tupi e os Macro-Jê tinham costumes e hábitos sociais distintos, é de se esperar que o impacto causado por estes grupos na rotina da sociedade sambaquieira tenha sido

(3) Cabe destacar que ainda são poucas as análises de bioantropologia que se voltaram para o estudo de indícios de violência em esqueletos de Sambaquieiros. 
de natureza distinta. O modo de ser Tupi baseiase numa "organização social flexível, um poder político baseado no prestígio e na importância religiosa do indivíduo, e que compartilham um mundo espiritual e ritual onde o xamanismo, a guerra e o canibalismo são noções extremamente importantes para a construção de sua identidade" (Silva et al. 2004:11). A guerra, o canibalismo e características tecnológicas inovadoras parecem ter sido elementos decisivos na invasão e no controle do território sambaquieiro.

Para os Macro-Jê não há, no estágio atual das pesquisas, indicador de um contato violento entre as duas sociedades. Ao contrário, há indícios de trocas, pela semelhança observada entre alguns artefatos, como pontas ósseas, e a suspeita de que a pesca em mar aberto tenha sido aprendida junto àquela sociedade, tendo-se em vista que o grupo, que posteriormente se instala na faixa costeira, é proveniente do interior do continente, originariamente agricultor/ceramista e pescador fluvial (Cordeiro 2005). Portanto, ainda que não se saiba qual a dimensão da influência exercida pelos Goitacá ou, até mesmo, se ela ocorreu, é possível que estes tenham incorporado alguns hábitos, como, por exemplo, a preferência por ambientes alagados, charcos e mangues, tornando-se "quase anfíbios" (Reclus 1899: 256), e "mais à maneira de homens marinhos que terrestres” (Salvador 1982: 107) por contato com a população do sambaqui, muito mais adaptada ao ambiente litorâneo (Cordeiro, 2004, 2005). Cabe destacar que a composição da aldeia Grande do Una é, em parte, caracterizada pelo significativo acúmulo de restos faunísticos, hábito típico dos sambaquieiros, situação recorrente em outros sítios arqueológicos filiados à tradição Una que ocorrem no interior do Brasil (Prous 1992).

Os Goitacá também resolviam suas disputas através do embate corporal, mas nada que se compare à guerra ritual considerada como "o drama obsessivo da existência Tupi” (Dean 1996: 48). Os Goitacá parecem ter se imiscuído no território sambaquieiro e estreitado laços de convivência, incorporando certos costumes. Os Tupinambá, por sua vez, mantiveram relativa distância espacial e implantaram suas aldeias segundo um padrão aglutinado (Fig. 1). O estudo das aldeias deste grupo, na Região dos
Lagos, está bastante avançado e não há indícios de incorporação de hábitos característicos dos sambaquieiros.

\section{A região dos Lagos: caracterização ambiental e social}

A descrição fisiográfica da área piloto foi estabelecida por Scheel-Ybert (1998,1999: 43-59), que informa que a planície costeira da Região dos Lagos se caracteriza por duas seqüências de sistemas lagunares, cuja evolução paleogeográfica está intimamente ligada às variações do nível do mar durante o Quaternário recente. O sistema lagunar interno compreende grandes lagoas (Saquarema e Araruama, entre outras), enquanto o sistema externo se constitui por uma seqüência de pequenas lagoas situadas na estreita depressão que separa dois cordões arenosos (Vermelha, Pernambuca, Brejo do Espinho etc.).

O clima da maior parte desta região é tropical úmido, quente e chuvoso no verão, com uma curta estação seca no inverno, caracterizado como Aw na classificação de Köppen. No extremo sudeste da Região dos Lagos, especificamente nos municípios de Cabo Frio, Búzios e Arraial do Cabo, o clima particularmente seco é classificado como Köppen $\mathrm{BSh}$, o que corresponde a uma variante do clima quente semi-árido. Isto é devido ao fenômeno de ressurgência, centrado nesta região da costa, que acarreta uma redução da precipitação local, a qual raramente excede $800 \mathrm{~mm} /$ ano (Barbière 1984).

A Região dos Lagos, assim como a maior parte da planície costeira do Brasil, é coberta pela restinga, ecossistema característico dos cordões arenosos litorâneos. A restinga é, na verdade, um mosaico de tipos de vegetação apresentando um zoneamento que vai da praia até o interior (Araújo \& Henriques 1984). Ela varia de comunidades abertas, com formações herbáceas e arbustivas ("restinga aberta") até a mata de cordões arenosos ("mata de restinga"). A restinga aberta inclui desde as formações de praias de vegetação psamófita-reptante até formações herbáceas brejosas, em pontos baixos do relevo, e formações arbustivas abertas ou fechadas, podendo formar moitas ou ter as copas contínuas, e ocorrendo no cordão externo, no cordão 


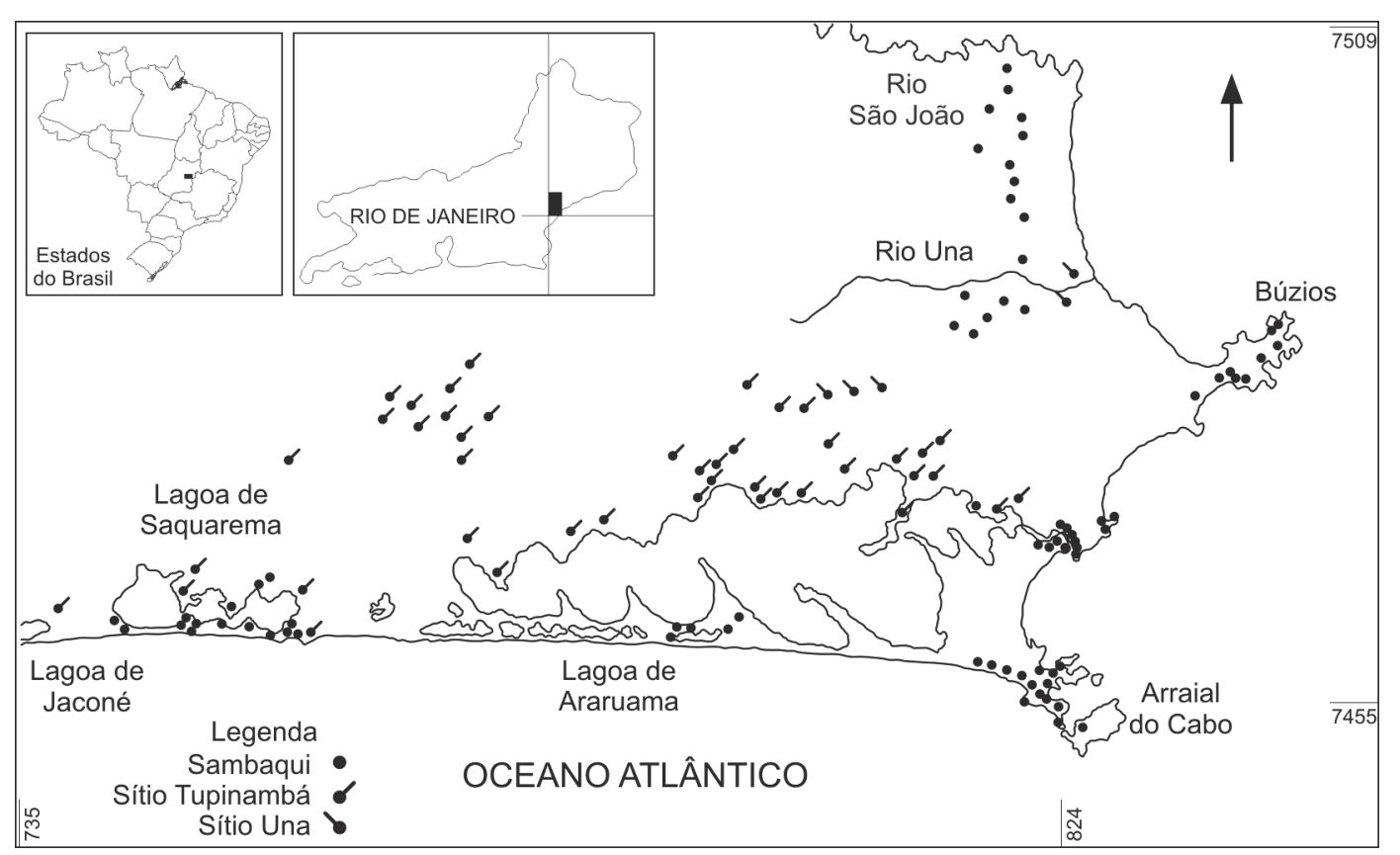

Fig. 1. Distribuição dos Sambaquieiros, Tupinambá e Goitacá na Região dos Lagos.

interno ou em pontos baixos do relevo. A mata de restinga se divide em um tipo de mata seca arenosa, com troncos finos bem ramificados e copas em geral contíguas, podendo ocorrer tanto no cordão externo quanto no cordão interno, e a mata de restinga inundada, localizada nos pontos mais baixos do relevo, e apresentando-se periódica ou permanentemente inundada (Araújo 2000).

Os afloramentos cristalinos próximos ao oceano, na região da Ilha de Cabo Frio até a península da Armação dos Búzios, apresentam associações vegetais que são únicas ao longo da costa e se caracterizam essencialmente pela vegetação rupestre típica dos costões abruptos, pela formação arbustiva de vertente e pela floresta xeromórfica de vertente, também conhecida como "mata seca". Esta floresta, embora ainda pouco conhecida, é distinta da mata de restinga e se aproxima mais, em alguns aspectos florísticos, da mata Atlântica.

A Região dos Lagos, há muito tempo, vem sendo estudada pelos arqueólogos brasileiros, 24 sítios de pescadores e coletores já foram alvo de escavações e estão disponíveis 57 datações radiocarbônicas (Quadro 1). A grande maioria das intervenções arqueológicas constatou a presença de sepultamentos e, em alguns sítios, há uma incidência significativa de esqueletos humanos. É inegável que o ritual era um fator preponderante no processo de construção dos sambaquis.

Buarque et al. (2003) demonstrou que, desde $2.600 \pm 160 \mathrm{BP}$, as aldeias Tupinambá já estavam em pleno funcionamento no complexo lagunar de Araruama. A presença de materiais europeus, tais como contas e metais usados para escambo e mesmo algumas alterações nos vasilhames indicam a sua permanência no momento da invasão européia (Buarque et al. 2003; Buarque \& Cordeiro 2003). Os relatos dos cronistas (Léry 1980; Staden 1974; Thevet 1575, 1944) são fartos em descrições que atestam que os Tupi haviam se tornado os novos senhores do litoral e a sua presença está registrada em vários pontos do litoral do Rio de Janeiro.

As tribos Goitacá eram divididas em quatro grupos, com o mesmo nome geral, acompanhado de epítetos diferentes: Goiatcá-Guaçu, GoitacáMopi, Goitacá-Meri, e Goitacá-Iacoritó. Essa distinção equivaleria a diferenças fáticas, do contrário não seriam necessárias entre eles. Thevet assinala que "os Goitacá são divididos 
entre dois bandos adversos, que se comem um ao outro, e cada bando em dois outros com somente esse nome ... os primeiros são aliados contra os últimos" (Thevet 2006: 279). Por outro lado, cada uma das tribos se distinguia, a começar pelo espaço ocupado, uma biota diferente para cada uma delas. Os Mopi, de acordo com Alfred Métraux (1929: 108), habitavam a atual região de Campos dos Goitacazes, no Rio de Janeiro; os Guaçu ocupavam o sertão (serra), os Meri e os Jacoritó a área entre Campos e o rio dos Bagres (atual rio Macaé). Hoje sabemos que este limite se estendia até a atual São Pedro da Aldeia. Cada uma inimiga "entranhável” da outra (Casal 1976: 203).

Apesar de seus epítetos revelarem diferenças, o nome geral nos remete a semelhanças; é possivel que sua unicidade estivesse relacionada com o mais profundo de suas tradições, ou seja, a sua origem. Os Goitacá são pertencentes ao tronco lingüístico Macro-Jê, e se isto desenha grandes diferenças, também nos remete a um universo único, como economia bimodal, sociedade de metades, características percebidas na produção cerâmica.

As datações obtidas no Grande do Una, $1.060 \pm 90$ BP (Cordeiro 2004) e $920 \pm 60$ BP (Cordeiro 2004), são uma referência cronológica confiável para a ocupação Macro-Jê na região dos Lagos, especialmente por estarem confirmadas por outras advindas de regiões em seu entorno. (Quadro 1). ${ }^{4}$ Sítio Frexeiras $-640 \pm 50(\mathrm{AD} 1280$ a 1410) e sítio Sapeatiba - 570 \pm 70 (AD 1300 a 1480).

\section{Os rituais funerários}

O projeto de construção dos sambaquis estava intrinsecamente relacionado com o ritual funerário. O sambaqui é decorrente de um intenso trabalho social que resultou na construção de uma paisagem domesticada, marcada por referências sentimentais relacionadas com os mortos.

(4) Não estamos considerando a referência mais antiga de $3.610 \pm 190$ para a cerâmica identificada como pertencente à tradição Una recuperada na camada I do sambaqui do Moa (Kneip 1994).
Conforme Gaspar (2004: 165), o cerne da sociedade sambaquieira parece ter sido garantir a preservação dos corpos, perspectiva que muito bem se coaduna em uma rotina social cujos mortos têm importância fundamental. Para os mortos foi criado local especial que se destaca na paisagem e se distingue de todos os outros. Um grupo que usufruía estabilidade territorial certamente contava com um conhecimento profundo sobre o ambiente e os processos naturais com ele relacionados. Os pescadores-coletores tiveram interesse e tempo suficiente para observar e desenvolver conhecimento sistemático sobre a decomposição de corpos, sejam eles humanos ou não, já que este aspecto da morte parece ter sido tema de interesse para esta sociedade. Escolheram, para construir o local de destino dos mortos, material que assegurasse a preservação de seus esqueletos. Com o acúmulo de conchas, criaram uma interferência no ambiente que neutralizou a acidez típica do solo brasileiro. Caso os sambaquieiros tivessem escolhido construir os cemitérios com material proveniente exclusivamente do próprio solo nada restaria dos corpos (Fig. 2).

Diferentemente dos Tupinambá e Goitacá, no que se refere aos Sambaquieiros, não há indícios de como lidavam com os corpos dos "outros", até mesmo porque a interação social com outros grupos culturais não parece ter sido uma dimensão importante no início da ocupação da faixa costeira da Região dos Lagos. Porém, constata-se uma variabilidade significativa na maneira de lidar com os corpos da própria população.

No caso dos construtores do Corondó, os acompanhamentos funerários (Machado 1984) permitem inferir alguns aspectos daquela sociedade, como o compartilhamento de tarefas por homens e mulheres. Os vários tipos de instrumentos, inclusive os associados a atividades geralmente vistas como masculinas, como as pontas ósseas para caça ou pesca, estão presentes em enterramentos de ambos os sexos, sem distinção.

A distribuição dos instrumentos evoca, também, a condição produtiva dos adultos, pois eles se restringem quase exclusivamente aos seus 
Tratamento dos Mortos entre os Sambaquieiros, Tupinambá e Goitacá que ocuparam a Região dos Lagos, Estado do Rio de Janeiro. Revista do Museu de Arqueologia e Etnologia, São Paulo, 17: 169-189, 2007.

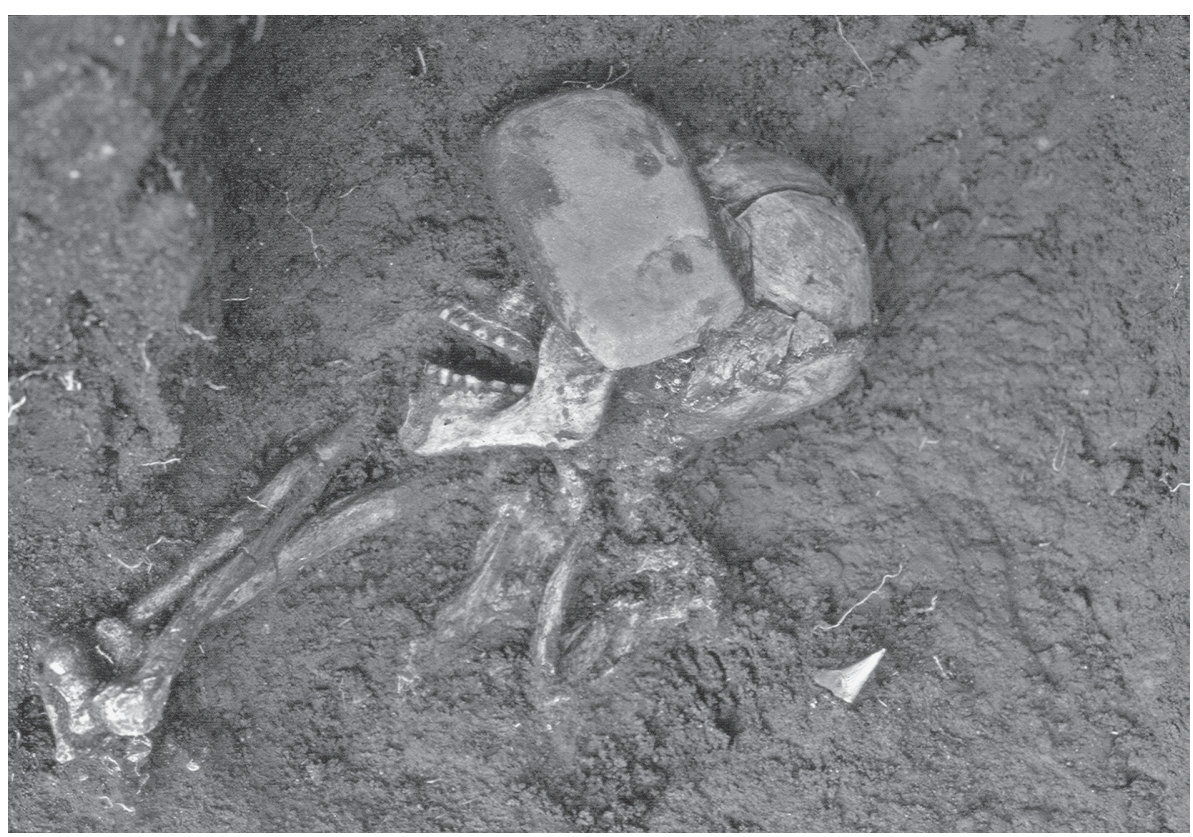

Fig. 2. Sepultamento em Sambaqui. (Foto M. Gaspar).

enterramentos. Por outro lado, adultos sem instrumentos fazem pensar em diferenciações sociais para além daquelas associadas à idade. Instrumentos apontam para a presença de indivíduos de destaque e/ou grupos de afinidade. ${ }^{5}$

Diferenciações sociais existiam certamente, pois apenas uma minoria da população apresenta enterramentos elaborados, com a presença de corante, instrumentos vários e

(5) O conceito de grupo de afinidade (unidade sociológica) foi definido por Gaspar (De Blasis 2004), é correlato ao de área funerária (evidência arqueológica). Área funerária refere-se a uma concentração de sepultamentos em um espaço/tempo delimitado. Assim, o conceito de grupo de afinidade é utilizado para designar o conjunto de indivíduos que foram sepultados próximos uns dos outros em uma área circunscrita ao longo de um período de tempo relativamente curto. Embora seja bem possível que relações de parentesco estejam estruturando tal arranjo, optou-se por defini-lo como "grupo de afinidade" justamente para que se investiguem os laços que ligam as pessoas ali enterradas sem modelos pré-concebidos, pois não é ainda possível descartar vinculações clânicas, políticas ou de outra natureza. A opção por um termo neutro possibilita investigações arqueológicas e biológicas sem um modelo interpretativo a priori rígido. adornos, enquanto a grande maioria de homens, mulheres, jovens e crianças não receberam quaisquer acompanhamentos, ou receberam apenas o corante. Parece ter sido uma sociedade marcada por hierarquia social, com status herdado: a imagem de uma sociedade igualitária não é coerente com o fato de que a algumas poucas crianças fossem atribuídos bens diferenciados em maior quantidade do que a adultos. A hipótese de status adquirido ao longo da vida parece não se sustentar diante da presença de adornos elaborados em enterramentos infantis. Os adornos infantis são invariavelmente compostos por um grande número de peças, em muito maior proporção do que nos adornos dos adultos, fossem eles homens ou mulheres, o que é indicativo do nivel de perda que teriam representado para a sociedade, no sentido da continuidade do grupo. Por outro lado, parece ter havido uma valorização das mulheres ao longo do tempo, pois os adornos só aparecem para elas nos níveis mais recentes de ocupacão.

Chama atenção a presença dos adornos de dentes humanos entre os acompanhamentos do Corondó. Os significados simbólicos específicos de que tenham sido portadores, sejam eles quais 
forem, guardam em si uma dimensão da intensidade com que os sambaquieiros percebiam e valorizavam os corpos. Dimensão presente em outros contextos, como no Sambaqui de Saquarema, onde se encontraram ossos humanos trabalhados em sepultamentos secundários (Kneip et al. 1995) ou no sambaqui da Pontinha, onde se verifica a prática da cremação (Kneip e Machado 1993).

A caça era uma fonte secundária de subsistência para os sambaquieiros quando comparada à pesca e à coleta de moluscos (Figuti 1993), mas os adornos de dentes de animais, terrestres e aquáticos têm forte presença nos enterramentos. As cosmologias ameríndias valorizam a caça enquanto elemento simbólico; quer se trate de povos caçadores, quer se trate de povos horticultores, esta simbologia está presente em todo o continente (Viveiros de Castro 2002: 357). A possível valorização simbólica da caça em uma sociedade do passado remoto, essencialmente pescadora e coletora, como os sambaquieiros, projetaria na longa duração um elemento essencial do universo simbólico ameríndio observado pela etnografia na atualidade.

Já ao falar do destino dos mortos entre os Tupinambá, é importante separar o tratamento dado aos de dentro do grupo daquele aplicado aos inimigos. De acordo com a narrativa dos cronistas dos séculos XVI e XVII, os Tupinambá valiam-se da antropofagia ritual para assegurar a coesão social; a guerra, a captura do inimigo e o posterior festim canibal não se davam em virtude de saciar a fome, mas para vingar os familiares e amigos mortos por outro grupo. A guerra aos contrários era o "principal fundamento desta sociedade" (Soares de Sousa 1971: 320), com a captura e a vingança funcionando como elementos estruturadores. Viveiros de Castro (1986: 650-660), numa reflexão sobre o significado da vingança e da antropofagia, as interpreta como restauradoras, pois elas resgatavam a relação do grupo com seu passado, como produtor, já que impulsionavam a máquina social para o futuro, criando a espiral da vingança, produzindo pessoas plenas, adultos-matadores-pais. Afirma que "sem inimigo não há a pessoa... sem mortos alheios não há, literalmente, vivos". O "outro" ocupava um lugar de honra na sociedade, seja na concessão de uma irmã, honra em matá-lo ou em morrer em suas mãos, sendo, portanto, a relação com o inimigo o valor social supremo (Viveiros de Castro 1992: 283-284).

Nas aldeias Tupinambá da Região dos Lagos, vivos e mortos partilhavam o mesmo espaço. Existem evidências significativas do destino dado aos mortos da comunidade e alguns indicadores do festim canibal referente aos inimigos. As práticas rituais que dizem respeito aos primeiros, e que se manifestam no registro arqueológico, indicam um padrão resistente a mudanças, pois permaneceram de forma quase inalterada desde os momentos iniciais da ocupação, por volta de 2.000 BP, até o período de contato com o europeu, no século XVI. Nas estruturas funerárias, dentro da área de moradia, eram sepultados os corpos de pessoas da comunidade, bem como as oferendas que faziam parte do ritual. As evidências que se referem ao inimigo se apresentam fora das estruturas e do espaço habitacional, onde alguns motivos decorativos presentes em fragmentos cerâmicos descartados na periferia do sítio trazem fortes indícios de que fazem parte de vasilhas que eram especialmente preparadas para recolher o sangue e as entranhas dos sacrificados (Buarque, no prelo).

As estruturas funerárias são o conjunto mais significativo encontrado no espaço habitacional. Elas são formadas por urna associada a tigelas pintadas, fogueiras, havendo, ainda, ocorrência de buracos de esteio. Estão presentes nas várias aldeias pesquisadas, seja nas anteriores ou póscontato com o europeu, variando no formato e quantidade de peças. A alta acidez do solo compromete a conservação dos restos esqueletais e, não raro, o esmalte dos dentes é a única evidência que permaneceu, havendo exemplos de ausência total de ossos, mas a associação recorrente não deixa dúvidas de que se trata de um espaço reservado aos mortos (Buarque, no prelo; Buarque, 2006). Apesar de existirem registros de sepultamento em covas feitas diretamente na camada argilosa, em outros pontos do território fluminense (Beltrão 1978: 41), na Região dos Lagos, as pesquisas apontam uma prática funerária restrita ao enterramento em urnas (Fig. 3) (Kneip et al. 1980; Buarque et 
Tratamento dos Mortos entre os Sambaquieiros, Tupinambá e Goitacá que ocuparam a Região dos Lagos, Estado do Rio de Janeiro. Revista do Museu de Arqueologia e Etnologia, São Paulo, 17: 169-189, 2007.

al. 2003; Gaspar et al. 2004: 115). No entanto, isto não significa que a prática realizada diretamente em covas no solo não tenha existido na região e a ausência dos achados pode ser resultante de sua destruição pela alta acidez devido à intensificação de práticas agrícolas desde tempos coloniais.

Nas fontes primárias, podemos encontrar referências às duas formas. Enquanto Gandavo (1980: 124) e Léry (1980: 247) descrevem o sepultamento diretamente no solo, Cardim (1980: 94), Soares de Sousa (1971: 330), Monteiro (1949: 416) e Thevet, em seus vários escritos (1944: 259; 1575: 926; 2006: 199), fazem menção à utilização de urnas fechadas protegendo os corpos. As narrativas e as imagens iconográficas revelam, ainda, a prática de envolvê-los em suas redes ou mantos. Em uma das aldeias pesquisadas, além da presença das vasilhas cerâmicas indicadoras desse ritual, temos um exemplo de enterramento primário, cuja observação foi possível devido às condições especiais do solo, que apresentava densas camadas naturais de conchas, resultantes da proximidade da laguna de Araruama, contribuindo para a preservação do material orgânico. Nesse exemplo, a correspondência anatômica dos segmentos ósseos foi evidenciada ainda no local de sepultamento e pode apontar para a possibilidade de o corpo ter sido amarrado por fios de algodão que não se preservaram (Buarque et al. 2003: 52-53).

As urnas estão enterradas abaixo do piso da aldeia, que ocorre em substrato arenoso, com espessura que varia de 0,40 a $0,60 \mathrm{~m}$, em covas que são abertas dentro do sedimento argiloso de cor ocre, atingindo uma profundidade de até $1,20 \mathrm{~m}$, dependendo das dimensões da urna. Em alguns casos, a cova recebe uma capa de argila cinza indicando a intenção de preparar uma "cama" para receber o corpo (Buarque, no prelo).

A distribuição das estruturas funerárias não obedece a um padrão fixo, podendo estar isoladas, enfileiradas em alguns sítios, ou associadas às cabanas como na aldeia de Morro Grande, onde as seis estruturas encontradas não estão agrupadas e guardam uma distância que varia de 20 a $40 \mathrm{~m}$, que reflete sua associação a unidades habitacionais.

O fogo é constante no ritual. As fogueiras são em geral circulares, com dimensões que variam de 0,30 a $0,50 \mathrm{~m}$ e espessura que pode atingir 0,20 $\mathrm{m}$ e estão localizadas ao lado do sepultamento. Elas ocorrem preferencialmente nos conjuntos mais complexos, com a presença de vasilhas pintadas, e fornecem indícios de que a oferenda alimentar foi expressiva; há marcas de queima na face externa e vestígios de impregnação de alimen-

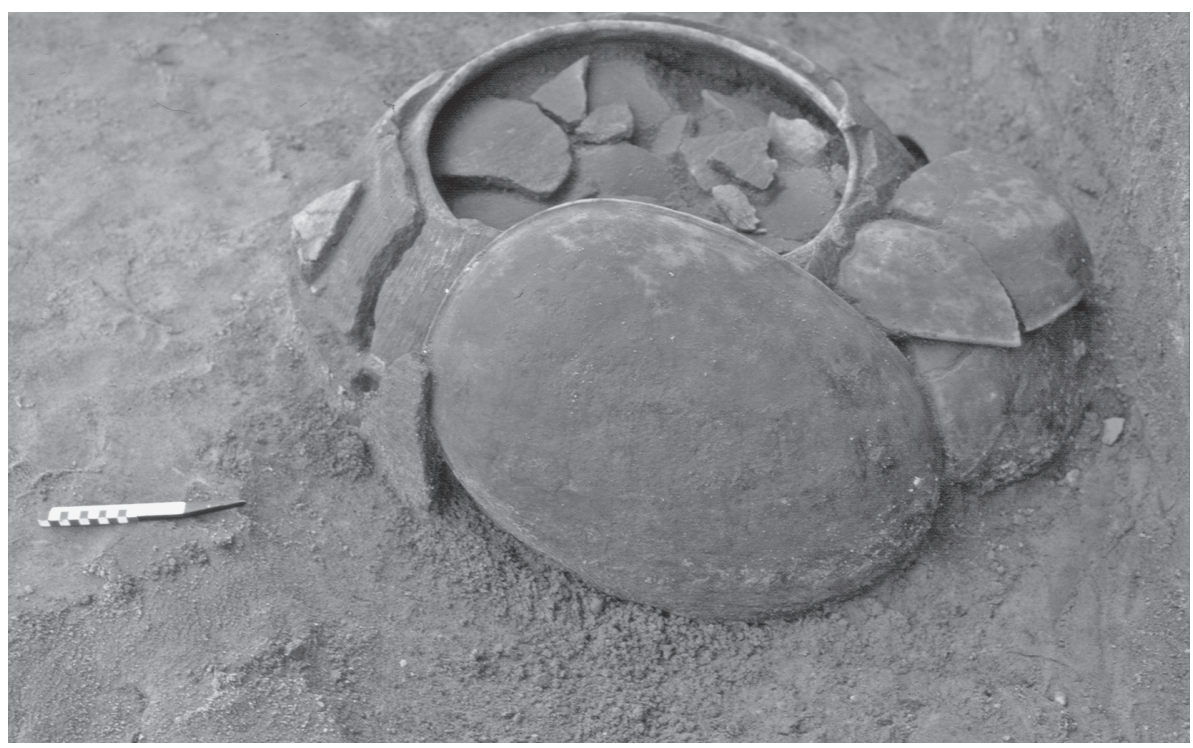

Fig. 3. Sepultamento em urna. Aldeia Morro Grande, Araruama. 
tos no interior de algumas tigelas que indicam o costume de acender fogos e deixar comida em torno do morto. A existência dessas estruturas comprova as descrições de cronistas, como Léry (1980: 247-248), Cardim (1980: 94), Gandavo (1980: 58), ou Thevet (2006: 199) que descrevem as práticas funerárias que os Tupinambá dispensavam aos que morriam de doença na aldeia. Léry faz referência ao costume dos nativos como forma de evitar a necrofagia do espírito Anhangá, de quem tinham temor especial. Thevet (2006: 199) menciona que a presença do fogo tem a função de espantar os maus espíritos e o alimento de saciar a fome da alma do morto.

As fontes quinhentistas e seiscentistas fornecem relatos consistentes de que a prática da antropofagia era um costume estrutural na construção da identidade Tupinambá. No entanto, nos sítios arqueológicos, pré ou póscontato, os seus indícios ainda são tênues, sendo um deles evidente na distribuição espacial dos vasilhames e fragmentos cerâmicos. A metodologia utilizada para a delimitação das aldeias permitiu observar uma divisão entre centro e periferia.

No centro da aldeia estão as habitações, a praça, o espaço funerário, evidenciados pelas peças cerâmicas bem conservadas ou fragmentos quebrados, resultantes de problemas tafonômicos, mas que parte significativa permite a restauração. $\mathrm{Na}$ periferia, estão ausentes as estruturas e são encontrados diversos tipos de fragmentos, onde a espessura e a decoração diferentes sugerem que foram intencionalmente rejeitados, fornecendo indícios de ser um local de descarte do lixo. Aí foram encontrados alguns fragmentos pintados cujos motivos figurativos lembram partes do corpo, ossos e vísceras. Um dos motivos a que Buarque $(2004 ; 2006)$ se refere é o esboço de um tronco, braços e pernas de uma figura humana decapitada, ou, numa outra possibilidade, a visão lateral de dois corpos em oposição. Merece destaque, ainda, um outro fragmento de tigela pintada num padrão intestinal que nos remete a uma cena antropofágica desenhada por De Bry (1992: 124), em que mulheres e crianças participam do festim e as vísceras do inimigo estão colocadas em um prato no meio da cena. A presença desses fragmentos fora do contexto funerário, que seria reservado aos mortos de dentro da comunidade, leva Buarque a pensar na hipótese de que estas peças cerâmicas tenham sido especialmente produzidas para receber as partes do corpo desmembradas em ritual antropofágico reservado aos inimigos. As referências nas fontes primárias (Staden 1974: 107) sobre a existência de utensílios que eram especialmente produzidos para os rituais de canibalismo reforçam a possibilidade de que essas vasilhas presentes nos sítios da Região dos Lagos tenham feito parte desse costume estruturador da sociedade Tupinambá (Buarque 2006).

Como no estudo dos Tupinambá, para se refletir sobre o destino dos corpos entre os Goitacá, é preciso separar o tratamento dado aos de dentro do grupo e aos de fora. No que se refere aos sítios arqueológicos em análise na Região dos Lagos - Grande do Una, Sapeatiba e Frexeiras - constatou-se a presença de dois tipos de sepultamentos: em um exemplo, nota-se a concentração de ossos humanos fragmentados e arrumados em forma de "montinho". Os integrantes da tribo eram sepultados em urnas e, segundo Vasconcellos (1943: 129), os “outros" tinham seus corpos fragmentados. As informações procedentes de escavações indicam que seus restos eram, também, depositados na própria aldeia e cobertos com alimentos, artefatos líticos e adornos (Cordeiro 2004: 107)

A primeira distinção para sepultamentos, "eles" e os "outros", é confirmada por descrições etnohistóricas. Vasconcellos (op. cit.) menciona o hábito de tratar os esqueletos pela fragmentação, provavelmente como uma forma de descaracterização da personalidade, sem, contudo, negar os valores do guerreiro, uma vez que depositavam alimentos como acompanhamento funerário, conforme mencionado acima. Há ossos humanos dispersos nos dois sítios Goitacá pesquisados: sítio Grande do Una e Aldeia de Sapeatiba. No sítio Grande do Una, nenhum esqueleto completo foi encontrado, seja em enterramento primário ou secundário. Os ossos humanos estavam muito fragmentados e dispostos em forma de "montinho". Sobre eles verificou-se sempre uma camada de carvões e de fauna (Cordeiro 2004). 
O maior fragmento mede $13,2 \mathrm{~cm}$ de comprimento. Um terço médio de fíbula direita, medindo $7,9 \mathrm{~cm}$ de comprimento, apresenta marcas de raspagem, demonstrando manipulação de ossos humanos. Esses ossos fragmentados também possuem acompanhamento de seixos, adornos e corantes. Aparentemente, não havia distinção de idade para ser considerado um "outro" pois em dois sepultamentos foram encontrados ossos infantis, fragmentados e associados a indivíduos adultos. Todos os conjuntos de fragmentos eram encimados por pequenas fogueiras e acompanhamento funerário composto por seixos, carvões e ossos faunísticos. Estes últimos poderiam ser considerados como oferenda alimentar, tal a abundância. Na primeira categoria, a "gente de comer" é, então, descaracterizada. Sua carne é tragada e seus ossos fraturados.

Há menção ${ }^{6}$ a enterramento em urnas no sítio Grande do Una, porém, somente no sítio de Sapeatiba, se constatou a presença dos dois tipos de sepultamentos: para "os outros", em montinhos (Fig. 4), em urnas para os iguais (Fig. 5). Dois sepultamentos foram encontrados, dentro de uma camada preta, argilo-arenosa, com abundante oferenda alimentar, sendo importante destacar no farto acompanhamento a presença de esqueletos de roedores quase inteiros.

No sítio Sapeatiba, o sepultamento de um indivíduo isolado foi encimado por um bolsão com carvões, contas, conchas, cerâmica, lascas de quartzo, lítico bruto e ossos faunísticos. A urna era envolvida por cinzas e carvões, o esqueleto estava sentado, originalmente voltado para o leste, com os membros inferiores fletidos, o crânio caído para a frente e a coluna repousando junto à parede oeste da urna. Junto ao esqueleto encontramos um colar de dentes de felino perfurados. No fundo da urna, internamente, havia areia branca. Na parte externa, foram encontrados dois dentes perfurados, uma concentração de pequenos ossos de preá e paca,

(6) Entrevistas realizadas com moradores da região informam que foram retiradas do sítio diversas urnas com enterramentos. uma columela branca polida arredondada, à semelhança de um tembetá, e um anzol de osso polido. Ainda, nas proximidades da urna, havia um cachimbo antropomorfo e, logo abaixo deste, uma porção de corante amarelo. É significativo que sepultamentos deste tipo tenham sido descritos para grupos Jê, no Rio de Janeiro, ainda no século XIX (Rugendas 1979). Pela quantidade e a disposição dos adornos, internos e externos à urna, é possível inferir que alguns dos itens encontrados não pertencessem ao morto, configurando assim uma homenagem, supondo que aquilo que lhe pertenceu em vida, muito provavelmente, estaria junto ao seu corpo.

O ritual entre os Goitacá era reservado aos iguais da mesma aldeia, todos os demais eram "outros", fossem eles Tupi, Portugueses, Franceses, Sambaquieiros e, inclusive, outros Goitacá de aldeias distintas. Fontes arqueológicas e etnográficas referem-se ao tratamento diferenciado dedicado aos integrantes do grupo tribal e aos "outros" ou inimigos.

\section{Conclusão}

A intenção de comparar o ritual funerário realizado por Sambaquieiros, Tupinambá e Goitacá coloca-se, inicialmente, por considerar que o colapso da sociedade sambaquieira está relacionado com o processo de expansão dos grupos ceramistas. A ocupação do território dos pescadores-coletores por volta do início da era Cristã, a diferença tecnológica dos agricultoresceramistas, a organização social destes grupos com forte valorização da guerra, a prática do canibalismo e o modo de vida dos

Sambaquieiros, que não parece ter privilegiado o combate corporal para resolver os seus conflitos, são aspectos que formaram um contexto social que tornou inviável a manutenção do hábito de construir sambaquis. Mas, sobretudo, cabe investigar o impacto no universo simbólico dos Sambaquieiros em decorrência da invasão de seu território por grupos cuja ingestão do "outro", através do canibalismo, era um aspecto fundamental da vida em sociedade.

Considerando os aspectos estruturais da cerimônia fúnebre entre os Sambaquieiros, 


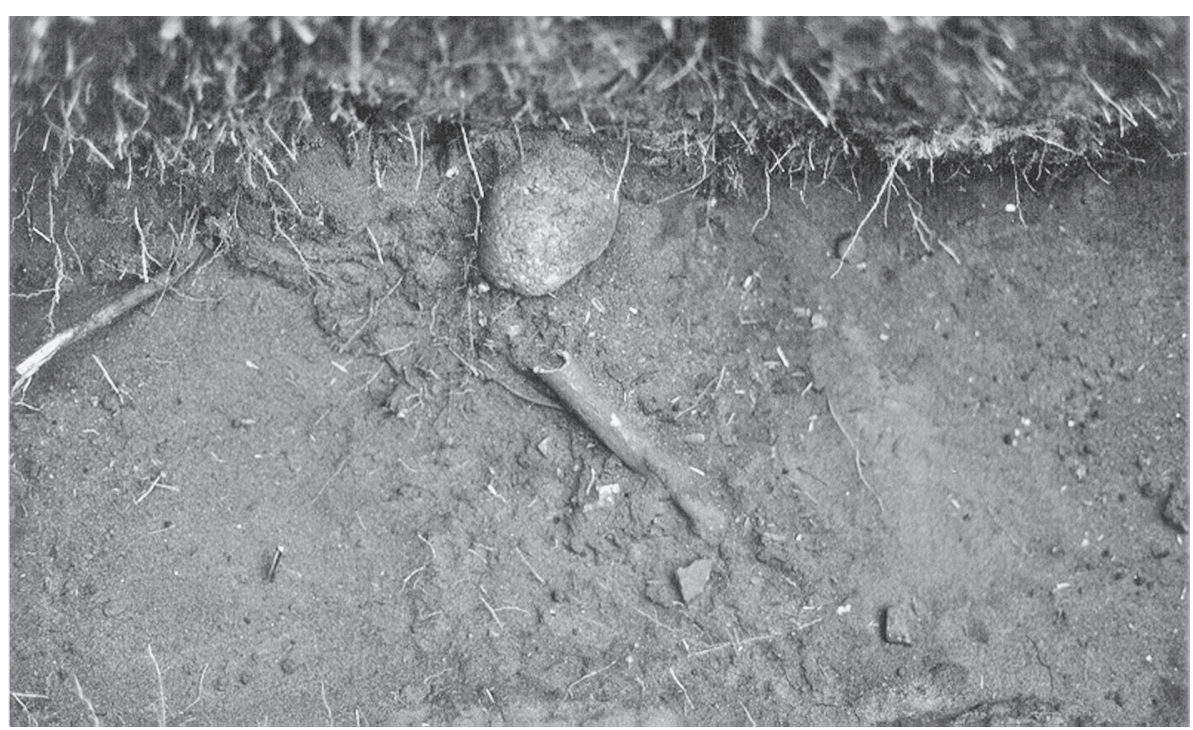

Fig. 4. Sepultamento dos "outros". (Foto: J. Cordeiro).

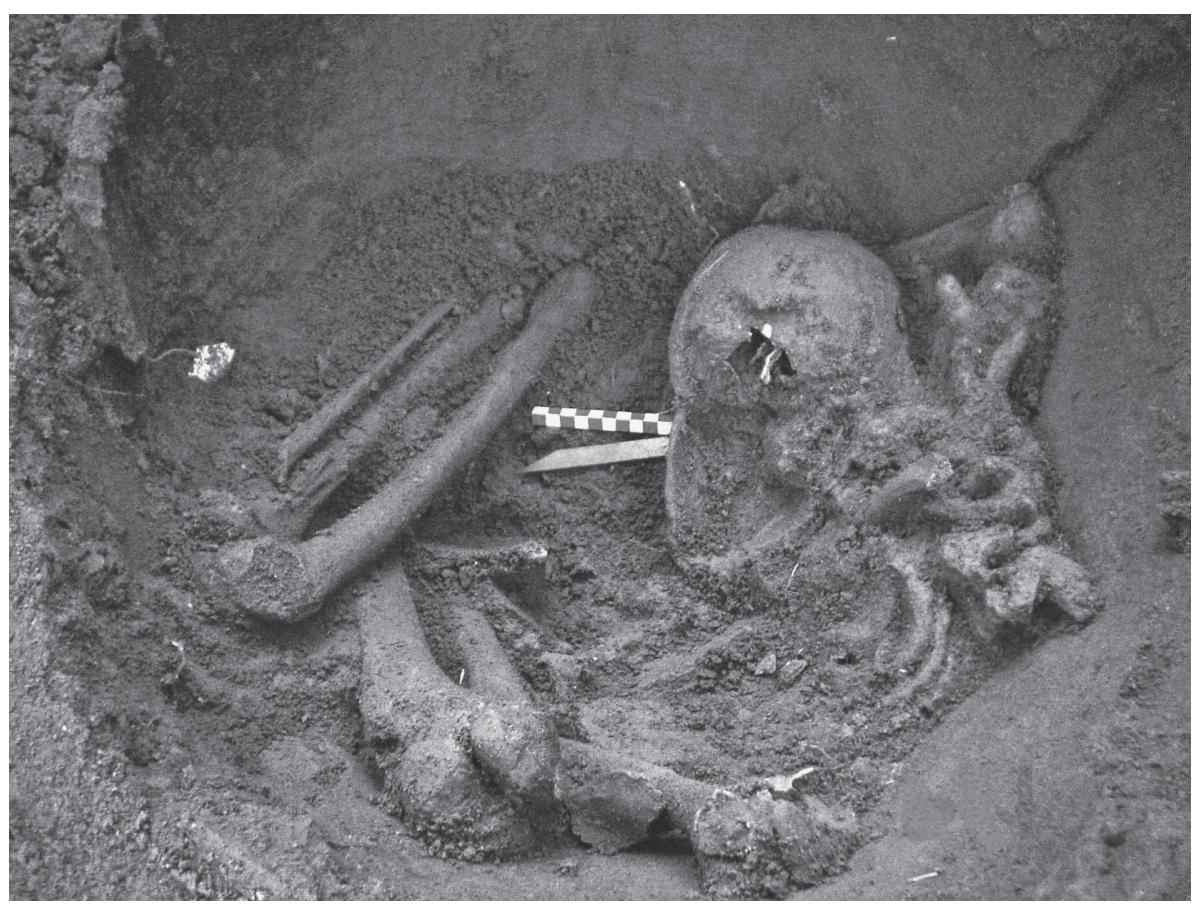

Fig. 5. Sepultamento em urna de membros do grupo. (Foto: J. Cordeiro).

Goitacá e Tupinambá, podem-se perceber, ao mesmo tempo, semelhanças e especificidades culturais. $\mathrm{O}$ fogo fúnebre, em cima ou ao lado do corpo, é uma presença constante, como também o é a associação entre o domínio alimentar e a morte. Comer com o morto através do festim fúnebre e/ou comer o morto são traços que persistem ao longo do tempo.

É evidente a preocupação dos Sambaquieiros com os processos de decomposição dos corpos, e este 
interesse se coaduna com a cosmologia dos nativos sul-americanos "pois é o corpo que faz a diferença aos olhos ameríndios" (Viveiros de Castro 2002: 381). Apoiamo-nos nas noções que embasam o Perspectivismo para refletir sobre diferenças e semelhanças nos rituais funerários encontrados no registro arqueológico de Sambaquieiros, Tupinambá e Goitacá. Trata-se da concepção, comum a muitos povos do continente americano, segundo a qual o mundo é habitado por diferentes espécies de sujeitos ou pessoas, humanas e nãohumanas, que o apreendem segundo pontos de vista distintos (Viveiros de Castro 2002:347). A ênfase na construção social do corpo é, por sua vez, um diferenciador das cosmologias ameríndias (Viveiros de Castro 2002: 388).

Seeger, Da Matta \& Viveiros de Castro (1979) destacaram a importância da corporalidade entre os nativos brasileiros. Viveiros de Castro (2002) propõe que essa noção tem fundamento cosmológico e que dessa forma é possível, por exemplo, entender melhor porque as categorias de identidade - individuais, coletivas, étnicas ou cosmológicas - exprimem-se tão freqüentemente por meio de idiomas corporais, em particular pela alimentação e pela decoração corporal. A pregnância simbólica universal dos regimes alimentares e culinários, essa universalidade manifesta justamente a idéia de que o conjunto de maneiras e processos que constituem os corpos é o lugar da emergência da diferença (Viveiros de Castro 2002:387-8).

Em certo sentido, Sambaquieiros, Tupinambá e Goitacá estão imersos em uma mesma cosmogonia, muito embora o registro arqueológico apresente-se de maneira tão distinta e apesar de seus sistemas de subsistência serem também diferenciados, já que Sambaquieiros tinham como principal atividade a pesca e a coleta, enquanto os Tupinambá e Goitacá eram agricultores. Considera-se que as cosmologias nativas privilegiam as interações simbólicas e sociais com o mundo animal, apesar de muitos grupos tribais serem produtores de alimentos (Viveiros de Castro 1996:194). ${ }^{7}$ Esta perspectiva abre um caminho para a correlação entre vários grupos que habitaram o que é hoje o território brasileiro sem que as reflexões se detenham na mera comparação entre os diferentes sistemas de subsistência.
Para os agricultores ceramistas (Tupinambá e Goitacá), a questão do destino do corpo se coloca de maneira distinta daquela dada pelos Sambaquieiros. Primeiro, a percepção do "outro" se impõe de maneira estruturadora para o funcionamento destas sociedades, pois enquanto Sambaquieiros inauguravam a colonização da faixa costeira, os agricultores ceramistas realizavam sua expansão sobre outros grupos culturais, entre os quais os próprios construtores de sambaquis. $\mathrm{O}$ “outro" se coloca, também, no domínio simbólico. Expansão territorial e ingestão do inimigo, através do canibalismo, parecem fazer parte de um mesmo sistema.

Dessa forma, ao falar do destino dos mortos entre os Tupinambá é importante separar o tratamento dado aos de dentro do grupo daquele aplicado aos inimigos. Por outro lado, e enfocando exclusivamente a sociedade sambaquieira, pode-se avaliar o impacto da invasão em seu território. No que pesem as conseqüências econômicas relacionadas com o compartilhar a área de captação de recursos com outro grupo populacional há, também, um significativo impacto no domínio simbólico. Como já dito, os sambaquieiros iniciaram a colonização da faixa costeira e, dessa forma, desbravaram-na impondo o seu domínio sem se defrontar com outros grupos humanos. Soberanos da costa, tiveram a sua trajetória de desenvolvimento social - a qual implicava crescimento demográfico e replicação de assentamentos desviada, ou mesmo interrompida, pela invasão de seu território.

Os Tupinambá e Goitacá apoiavam a sua expansão na conquista do "outro", sendo a guerra e o canibalismo a melhor expressão desse modo de vida, que resultava no aprisionamento e expropriação dos corpos, que causaram enorme impacto no mundo simbólico dos

(7) Segundo Viveiros de Castro (2002:357), "No que respeita à caça, sublinhe-se que se trata de uma ressonância simbólica, não de uma dependência ecológica: horticultores aplicados como os Tukuna ou os Juruna - que além disso são principalmente pescadores - não diferem muito dos grandes caçadores do Canadá e Alasca, quanto ao peso cosmológico conferido à predação animal..." 
sambaquieiros. Eliminou-se, dessa maneira, a razão de continuar erigindo sambaquis pois, sem mortos e sem corpos não havia mais motivo para continuar a edificação. Não queremos dizer com isso que todos os sambaquieiros foram eliminados pelos ceramistas, ao contrário, é bem possível que muitos tenham sido subjugados e incorporados por tais grupos tribais, ou mesmo migrado para outros ambientes litorâneos. O que se quer destacar é que o programa de construção de sambaquis sofreu mudanças perceptiveis na estratigrafia e que depois se tornou insustentável no momento em que os ceramistas se instalaram em seu território.

Com a invasão européia, os Tupinambá, que buscavam reproduzir a vida social através da guerra e da morte gloriosa em terreiro inimigo, encontraram como alternativa a fuga para o interior, ou a violência e a morte por doenças, fome ou pela guerra do conquistador. Os guerreiros perderam o direito à vingança que possibilitava a reprodução da vida social, e a sociedade, desestruturada, em conseqüência, entrou em colapso. A população Tupinambá, que permanecera por cerca de 2 milênios na Região dos Lagos, com o impacto da presença européia, desapareceu em 60 anos.

Segundo Cordeiro (2004), aos Goitacá, restou a morte, a redução de São Pedro e a fuga para o interior. A resistência possibilitou que, ainda no século XIX, alguns hábitos permanecessem, como o de cortar os cabelos com "cristal" e enrolar as meninas em casca de Jequitibá, dançar e dormir no chão, passando pela "jogatina" de flecha no cipó. Esses costumes perenizados em Minas Gerais e no norte do estado do Rio de Janeiro sugerem que este grupo estava longe do extermínio pretendido pelo invasor.

GASPAR, M.D.; BUARQUE, A.; CORDEIRO, J.; ESCÓRCIO, E. Treatment of the dead amongst the Sambaquieiros, Tupinambá and Goitacá that occupied the "Região dos Lagos", Rio de Janeiro State. Revista do Museu de Arqueologia e Etnologia, São Paulo, 17: 169-189, 2007.

Abstract: This paper intends to establish a comparative dimension amongst different cultural groups which have occupied the "Região dos Lagos", at the Southeast shore of Brazil and to focus the study on the funerary ritual - in this case understood as a central aspect of social life. We present the colonization process of the region, considering it as a pilot area that keeps important information about the occupation of the east portion of South America. Thus, the study approaches colonization, social interaction and control of the territory related to the Sambaquieiro, Tupi and Macro-Jê groups and intends to link information deriving from archaeology, anthropology, history and the reports of the chroniclers.

Keywords: Funerary ritual - Sambaquieiros - Tupinambá and Goitacá.

\section{Referências bibliográficas}

AFONSO, M. C. ; DE BLASIS, P.

1994 Aspectos da formação de um grande sambaqui: alguns indicadores em Espinheiros II, Joinville, SC. Revista do Museu de Arqueologia e Etnologia 4:21-30.
ARAÚJO, D.S.D.; HENRIQUES, R.P.

1984 Análise florística das restingas do Estado do Rio de Janeiro. In: Lacerda, L.D.; Araújo, D.S.D.; Cerqueira, B. (Orgs.) Anais do Simpósio sobre Restingas Brasileiras, 
Tratamento dos Mortos entre os Sambaquieiros, Tupinambá e Goitacá que ocuparam a Região dos Lagos, Estado do Rio de Janeiro. Revista do Museu de Arqueologia e Etnologia, São Paulo, 17: 169-189, 2007.

CEUFF: Restingas, Origem, Estrutura, processos, Universidade Federal Fluminense/ CEUFF: $159-193$.

ARAÚJO, D.S.D.

2000 Análise florística e fitogeográfica das restingas do Estado do Rio de Janeiro. Rio de Janeiro. Tese Doutorado. Universidade Federal do Rio de Janeiro - Programa de pósGraduação em Ecologia.

BARBIÈRE, E.B.

1984 Cabo Frio e Iguaba Grande, dois microclimas distintos a um curto intervalo espacial. In: Lacerda, L.D.; Araújo, D.S.D.; Cerqueira, B. (Orgs.) Anais do Simpósio sobre Restingas Brasileiras, Restingas, Origem, Estrutura, processos, Universidade Federal Fluminense/ CEUFF: 253-274.

BELTRÃO, M.C.

1978 Pré-história do Estado do Rio de Janeiro. Rio de Janeiro: Forense Universitária-SEEC, 276p.

BROCHADO, J.

1984 An Ecological Model of the Spread of Pottery and Agriculture into Eastern South America. Urbana-Champaign, University of Illinois. Tese de Doutorado.

BUARQUE, A.

2004 Etude de l'occupation Tupinambá dans la région sud-est de l'Etat de Rio de Janeiro. Projeto de Doutorado apresentado à Université Paris I, Panthéon-Sorbonne (mimeo).

2006 L'occupation Tupinambá à Rio de Janeiro, Brésil, XV Anais Congresso UISPP, Lisboa, Portugal, Setembro 2006: 206.

Prelo As estruturas funerárias das aldeias Tupinambá da região de Araruama, RJ. In: A. Prous; T.A. Lima (Eds.) Os ceramistas Tupiguarani.

BUARQUE, A.; RODRIGUES-CARVALHO, C.; SILVA, E.C.

2003 Programa Funerário dos Tupinambá em Araruama, RJ - Sítio Bananeiras, Revista do Museu de Arqueologia e Etnologia, São Paulo, 13: 39-55.

BUARQUE, A.; CORDEIRO, J.

2003 O Sítio Serrano: Franceses e Tupinambá desconheciam o testamento de Adão. XII Congresso da Sociedade de Arqueologia Brasileira-SAB "Arqueologias da América Latina”, São Paulo, SP. Resumos: 165.

CARDIM, F.

1980 Tratados da Terra e Gente do Brasil. Belo Horizonte: Editora Itatiaia Ltda; São Paulo: EDUSP, 206p.
CASAL, A.

1976 Corrografia Brasílica. Belo Horizonte: Ed. Itatiaia; São Paulo: EDUSP, 203 p.

CORDEIRO, J.

2004 A Primeira face da tradição: Os Goitacá. Da História e identidade dos que não deitaram letras. Dissertação de Mestrado em História, Universidade Severino Sombra, Vassouras, Rio de Janeiro, 203p.

2005 Nem cães, nem lobos: os Guerreiros Goitacá. Pilares da História, Rio de Janeiro, n. 5.

CRANCIO, F.; KNEIP, L.M.

1994 A cerâmica. In: KNEIP, L.M. (Coord.) Cultura material e subsistência das populações pré-históricas de Saquarema, RJ. Documentos de Trabalho (Série Arqueologia), Rio de Janeiro, Museu Nacional, 2: 23-28.

DEAN, W.

1996 A ferro e fogo: a história e a devastação da mata atlantica brasileira. Rio de Janeiro, Companhia das Letras: 4.

DE BLASIS, P.A.

2002 Os mais antigos soberanos da costa. In: Anais do XI Congresso da Sociedade de Arqueologia Brasileira-SAB. Rio de Janeiro, RJ: 43-44.

DE BLASIS, P.A.; EGGERS, S; LAHRS, M.M; FIGUTI, L; AFONSO, M.C; GASPAR, M.D.

1998 Padrões de Assentamentos e Formação de Sambaquis em Santa Catarina. Revista do Museu de Arqueologia e Etnologia, São Paulo, 8: 319-321.

DE BRY, $T$.

1992 Le Théâtre du Nouveau Monde. Paris : Gallimard. 227p.

DIAMOND, J.

2005 Colapso. Como as sociedades escolhem o fracasso ou o sucesso. Rio de Janeiro, São Paulo: Editora Record. 685 p.

DIAS JUNIOR, O.

1980 Rio de Janeiro: a tradição Itaipu e os sambaquis. Anu. Div. Ci., Goiânia, 7: 33-42.

1994/1995Considerações a respeito dos modelos de difusão da cerâmica tupi-guarani no Brasil. Revista de Arqueologia, São Paulo, 8 (2): 113-132.

1998 O índio no Recôncavo da Guanabara. Revista do Instituto Histórico e Geográfico Brasileiro, Rio de Janeiro, a. 159, n. 399: 399-641.

DIAS JUNIOR, O.; CARVALHO, E. 1984 A Fase Itaipu, RJ. Novas considerações. 
Arq. Mus. Hist. Nat., Belo Horizonte, 9: 95-106.

ESCÓRCIO, E.; GASPAR, M.D.

2005 Indicadores de diferenciação social e de gênero dos pescadores-coletores que ocuparam a Região dos Lagos-RJ. Cadernos do LEPAARQ, II (3), Textos de Antropologia, Arqueologia e Patrimônio. Editora da Universidade Federal de Pelotas: $15-27$.

FIGUTI, L.

1993 O homem pré-histórico, o molusco e o sambaqui: considerações sobre a subsistência dos povos sambaquieiros. Revista do Museu de Arqueologia e Etnologia, São Paulo, 3: 67 - 80.

FISH, S.K.; DE-BLASIS, P.; GASPAR, M.D.; FISH, P.R.

2000 Eventos incrementais na construção de sambaquis, litoral sul do estado de Santa Catarina. Revista do Museu de Arqueologia e Etnologia, São Paulo, 10: 69-88.

GANDAVO, P.M.

1980 Tratado da Terra do Brasil. História da Terra de Santa Cruz. Coleção Reconquista do Brasil. São Paulo: EDUSP. 150 p.

GASPAR, M.D.

1991 Aspectos da organização social de um grupo de pescadores, coletores e caçadores: Região compreendida entre a Ilha Grande e o delta do Paraíba do Sul, Estado do Rio de Janeiro. São Paulo. 374p. (Doutorado em Arqueologia), Programa de Pós-graduação em Arqueologia, Faculdade de Filosofia, Letras e Ciências Humanas, USP.

1993 Pescadores, coletores e caçadores préhistóricos do litoral sudeste do Brasil: organização social e adaptação ambiental. In: Congresso Internacional De Ciências Antropológicas Y Etnológicas, Las Dimensiones Culturales Y Biologicas Del Cambio Global, 13. México. Resumenes: 153.

2004 Cultura: comunicação, arte, oralidade na pré-história do Brasil. Revista do Museu de Arqueologia e Etnologia, São Paulo, 14: 153-168.

GASPAR, M.D.; TENORIO, M.C.; BUARQUE, A.; BARBOSA-GUIMARÃES, M.; OLIVEIRA, J.C.; SCHEEL-YBERT, R.

2004 Histórico e Principais Resultados do Projeto de Investigação: O Aproveitamento Ambiental das populações Préhistóricas do Rio de Janeiro. Arquivos do Museu Nacional, Rio de Janeiro, 62 (2): 103-129.
HECKENBERGER, M.; NEVES, E.G.; PETERSEN, J.B.

1998 De onde surgem os modelos? As origens e expansões Tupi na Amazônia Central, Revista de Antropologia, São Paulo, 41 (1): 69-96.

KNEIP, L.M.

1994 Introdução. Documentos de Trabalho (Série Arqueologia), Rio de Janeiro, Museu Nacional, 2: 3-6.

2001 O Sambaqui de Manitiba I e Outros Sambaquis de Saquarema, RJ. Documento de Trabalho, Série Arqueologia, Rio de Janeiro.

KNEIP, L.M.; MONTEIRO, A.M.F.; SEYFERTH, G.

1980 A Aldeia Pré-histórica de Três Vendas. Araruama, Estado do Rio de Janeiro. Revista do Museu Paulista, São Paulo, Nova série, XXVII: 283-337.

KNEIP, L.M.; MACHADO, L.C.

1993 Os ritos funerários das populações préhistóricas de Saquarema, RJ: sambaquis da Beirada, Moa e Pontinha. Documentos de Trabalho (Série Arqueologia), Rio de Janeiro, Museu Nacional, 1: 76.

KNEIP, M.L.; MACHADO, L.C.; CRANCIO, F.

1995 Ossos humanos trabalhados e biologia esqueletal do Sambaqui de Saquarema, RJ. In: Kneip, M.L. (Coord.) Documentos de Trabalho (Série Arqueologia). Rio de Janeiro, Museu Nacional, 3: 13-31.

KLÖKLER, D.M.

2001 Construindo ou deixando um sambaqui? Análises dos sedimentos de um sambaqui do litoral meridional brasileiro. Dissertação de Mestrado, São Paulo, Faculdade de Filosofia, Letras e Ciências Humanas, Universidade de São Paulo.

LATHRAP, D.W.

1970 The Upper Amazon. Ancient Peoples and Places, 70. New York: Praeger. 256 p.

LÉRY, J. DE

1980 Viagem à Terra do Brasil. Coleção Reconquista do Brasil. São Paulo, EDUSP. 302 p.

LESSA, A.; MEDEIROS, J.C.

2001 Reflexões preliminares sobre a questão da violência em populações construtoras de sambaquis: análise dos sítios Cabeçuda (SC) e Arapuan (RJ). Revista do Museu de Arqueologia e Etnologia, São Paulo, 11: 77-93.

LIMA, T.A.

1991 Dos mariscos aos peixes: um estudo zooarqueológico de mudança de subsistência 
na pré-história do Rio de Janeiro. Tese de Doutorado. São Paulo, Faculdade de Filosofia, Letras e Ciências Humanas da USP.

LUBY, E.M.; GRUBER, M.F.

1999 The Dead must be Fed: Symbolic Meanings of the Shellmounds of the San Francisco Bay Area. Cambridge Archaeological Journal, 9 (1): 95-108.

MACHADO, L.M.C.

1984 Análise dos Remannescentes Ósseos Humanos do Sítio Arqueológico Corondó. Aspectos Biológicos e Culturais. Série Monografias. Instituto de Arqueologia Brasileira. Rio de Janeiro, 1. $425 \mathrm{p}$.

MAYBURY-LEWIS, D.

1979 Dialectical societies: the Gê and Bororo of Central Brazil. Cambridge: Harvard University Press.

MAUSS, M.

1974 Ensaio sobre as variações sazoneiras das sociedades esquimó. Antropologia e Etnologia. São Paulo, EPU/EDUSP: $237-$ 331.

MÉTRAUX, A.

1929 Les Indiens Waitaká. Journal de la Société des Americanistes de Paris. Protat Freres. Nouvelle Série, XXI: 108.

MONTEIRO, J.

1949 Relação da Província do Brasil, 1610. In: Serafim Leite, S.I. História da Companhia de Jesus no Brasil. Tomo VIII, Rio de Janeiro, Instituto Nacional do Livro: 393-425.

NOELLI, F.

1996 As hipóteses sobre o centro de origem e rotas de expansão dos Tupi, Revista de Antropologia, São Paulo, 39 (2): 7-53.

PROUS, A.

1992 Arqueologia Brasileira. Brasília: Editora UNB. 613 p.

RECLUS, E.

1899 Geographia, Ethnographia e Estatística dos Estados Unidos do Brazil. Rio de Janeiro: Ed. H. Garnier, Livreiro-Editor: 256.

ROBRAHN-GONZÁLEZ, E.M.

1996 A Ocupação Ceramista Pré-Colonial do Brasil Central. Origens e Desenvolvimento. Tese de Doutorado. São Paulo, Faculdade de Filosofia, Letras e Ciências Humanas da Universidade de São Paulo.

RUGENDAS, J.M.

1979 Viajem Pitoresca através do Brasil. Coleção Reconquista do Brasil, Nova Série, v.2, 8a ed. Belo Horizonte/São Paulo, Itatiaia/ EDUSP.

SALVADOR, FREI VICENTE

1982 História do Brasil 1500-1627. Coleção Reconquista do Brasil, Nova Série, vol. 49. São Paulo: EDUSP. 437 p.

SCATAMACCHIA, M.C.M.

1990 A Tradição Policrômica no Leste da América do Sul evidenciada pela ocupação Guarani e Tupinambá: Fontes Arqueológicas e EtnoHistóricas. Tese de Doutoramento. Faculdade de Filosofia, Letras e Ciências Humanas da Universidade de São Paulo. Mimeo.

SCHEEL-YBERT, R.

1998 Stabilité de l'Ecosystème sur le littoral sud-est du Brésil à l'Holocène Supérieur (5.500 1400 ans BP) - Les pêcheurs-cueilleurschasseurs et le milieu végétal : apport de l1Anthracologie. Tese de Doutorado. Université Montpellier II.257 p.

1999 Paleoambiente e paleoetnologia de populações sambaquieiras do sudeste do estado do Rio de Janeiro, Revista do Museu de Arqueologia e Etnologia, São Paulo, 9: 43-59.

SEEGER, A.; DA MATTA, R.; VIVEIROS DE CAS. TRO, E.

1979 A construção da pessoa nas sociedades indígenas brasileiras. Boletim do Museu Nacional, 32: 2-19.

SILVA, F.A., NEVES, E.G.; DE BLASIS, P.A.

2004 Brasil Tupi. Museu de Arqueologia e Etnologia, USP. 30p.

SOARES DE SOUSA, G.

1971 Tratado Descritivo do Brasil em 1587. São Paulo: EDUSP. 389 p.

STADEN, H.

1974 Duas Viagens ao Brasil, Coleção Reconquista do Brasil. São Paulo: EDUSP. 216 p.

THEVET, A.

1575 La Cosmographie Universelle d'André Thevet Cosmographe du Roy, Chez Pierre l'Huillier, rue S. Jacques, à l'Oliuier, Avec privilège du Roy, Tome Quatrième, Paris.

1944 Singularidades da França Antártica, a que outros chamam de América. Série 5a, Vol. 229, São Paulo: Companhia Editora Nacional.

2006 Histoire d'André Thevet Angoumoisin, cosmographe du Roy, de deux Voyage par luy faits aux Indes Australes et Occidentales. Édition Critique par Jean-Claude Laborie et Frank Lestringant. Genève: Librairie Droz. 496 p. 
URBAN, G.

1992 A história da cultura brasileira segundo as línguas nativas. In: Cunha, M.C. (Org.) História dos Índios no Brasil. São Paulo, Cia. das Letras/ FAPESP: 87-102.

\section{VAN GENNEP, A.}

1978 Os ritos de passagem. Petrópolis: ed. Vozes. VASCONCELLOS, S. DE

1943 A vida do Venerável Padre José de Anchieta. Rio de Janeiro: Imprensa Nacional.
VIVEIROS DE CASTRO, E.

1986 Araweté, os Deuses Canibais. Rio de Janeiro: Jorge Zahar Editor/ANPOCS. 744 p.

1992 From the enemy's point of view. Humanity and divinity in an Amazonian society. Chicago: the University of Chicago Press. 407 p.

1996 Comentários ao artigo de Francisco Noelli, Revista de Antropologia, Vol. 39, № 2, 55-60.

2002 A Inconstância da Alma Selvagem. São Paulo: Cosac Naify Edições Ltda. 550 p.

Recebido para publicação em 20 de fevereiro de 2007. 